\title{
The influence of chemical protection on the content of heavy metals in wheat (Triticum aestivum L.) growing on the soil enriched with granular sludge
}

\author{
E. Wołejko • B. Lozowicka • P. Kaczyński • \\ R. Konecki • M. Grobela
}

Received: 28 March 2017 / Accepted: 20 July 2017 / Published online: 31 July 2017

(C) The Author(s) 2017. This article is an open access publication

\begin{abstract}
The presence of heavy metals in Triticum aestivum L. growing on the soil enriched with granular sludge after chemical protection was observed. The five variants of treatments using herbicide (Chwastox Turbo 340SL) and four fungicides (Topsin M 500SC, Amistar 250SC, Artea 330EC, and Falcon 460EC) were performed. On control and experimental plots, the concentration of $\mathrm{Ni}, \mathrm{Pb}, \mathrm{Cr}$, and $\mathrm{Cu}$ in wheat leaves were in the range $0.32-0.99,0.92-1.57,0.89-6.31$, and $7.08-$ $12.59 \mathrm{mg} / \mathrm{kg}$ and in grains 0.03 to $0.11,0.14-0.25$, $0.11-0.76$, and $1.06-1.46 \mathrm{mg} / \mathrm{kg}$, respectively. The concentration of $\mathrm{Pb}$ in grain protected by MCPA and 2,4-D with thiophanate-methyl and azoxystrobin was higher than the maximum levels of $0.20 \mathrm{mg} / \mathrm{kg}$ D.M. The bioconcentration factor (BCF) differed and depended on chemical protection. The highest value of BCF was achieved for $\mathrm{Cd}$. The statistical analysis showed a significant correlation between concentration of metals and quality parameters of wheat. One observed significant
\end{abstract}

\footnotetext{
E. Wołejko $(\bowtie)$

Department of Chemistry, Biology and Biotechnology, Białystok University of Technology, Wiejska 45 E, 15-351 Białystok,

Poland

e-mail: e.wolejko@pb.edu.pl

B. Łozowicka · P. Kaczyński · R. Konecki

Laboratory of Pesticide Residues, Institute of Plant Protection -

National Research Institute, Chełmońskiego 22, 15-195 Białystok, Poland

M. Grobela

Institute of Plant Protection - National Research Institute,

Węgorka 20, 60-318 Poznań, Poland
}

negative correlations between $\mathrm{Ni} /$ Zeleny sedimentation value $(r=-0.51)$ and between $\mathrm{Pb} /$ starch content $(r=-0.57)$. Positive correlations were observed between $\mathrm{Cd} / \mathrm{yield}$, the number of grains/ergosterol concentration (respectively, $r=0.41, r=0.55, r=0.56$ ), and $\mathrm{Zn} /$ thousand grain weight $(r=0.50)$ at a $p \leq 0.05$.

Keywords Heavy metal · Granular sludge $\cdot$ Herbicide Fungicide $\cdot$ Grain · Plant

\section{Introduction}

Wheat (Triticum aestivum L.) is one of the most popular cereals cultivated in the world, holding a large yield potential. Versatile use in food, feed, and pharmaceutical field forces the production of high quality and quantity yield (Singh et al. 2010).

Wheat belongs to plants susceptible to attacks of fungal pathogens, pests, and weeds, which lead to significant yield losses (Lozowicka et al. 2012). The severity of their occurrence is related to climatic conditions, monoculture crop with the simplification of cultivation methods, or ineffective protection (Bjorling-Poulsen et al. 2008).

In wheat agrophage control, one commonly uses agronomic, biological, mechanical, and chemical methods; the last provides extremely effective protection. Used plant protection products contribute not only to inhibiting the growth of pathogens, pests, and weeds but also to stimulating the growth, the presence of assimilation pigments, and yield of plants (Balba 2007; Łozowicka et al. 2016). 
Modern fungicides used in wheat protection on the basis of strobilurins, triazoles, and amines inhibit the growth of the fungus through the stop electron transfer between cytochrome $\mathrm{b}$ and cytochrome $\mathrm{c}$, which reduces oxidation of nicotinamide adenine dinucleotide (NADH) and adenosine triphosphate (ATP) synthesis (Balba 2007; Rosales-Conrado 2009) as well as inhibits sterol biosynthesis (Jabłońska-Trypuć et al. 2017).

Among the large group of herbicides utilized in wheat production, MCPA and dicamba (Pernak et al. 2011) are still being popular, in combination or either alone. These compounds provide broadleaf weed control. From another point of view, they may negatively influence crop and humans (Pernak et al. 2011). These herbicides may be characterized by resistance to biodegradation processes and they may influence the amount of specific microbial species, thus the growth and quality of crops ( Lawniczak et al. 2016).

In the agronomic methods, one of the innovative solutions to improve quality parameters of soil sediments is using an alternative source of organic matter and nutrients (Birkhofer et al. 2008). The sewage sludge may be an excellent product which makes it possible to recycle valuable components such as organic matter, nitrogen, phosphorus, and other nutrients for plants. Fertilization with stabilized settlements contributes to increasing the amount of humus in soil as well as to improving its quality. It may also facilitate increasing the yield of various crops such as cereals, vegetables, shrubs, and trees (Wuana and Okieimen 2011).

Searching for new solutions reducing the deficit of soil organic matter results from insufficient production of manure. Therefore, an interesting option is to use sewage sludge on crops where gradual releasing nutrients ensures plant growth at a satisfactory level (Zhao et al. 2001). On the other hand, in addition to the positive aspects of the favorable biological compounds, deposits can contain harmful and toxic compounds, e.g., heavy metals (Wołejko et al. 2014).

The application of sludge on production soil due to the stability of heavy metals in the environment can contribute to their inclusion into the biological cycle (Bose and Bhattacharyya 2008). Consequently, the plants absorbing soil nutrients can also assimilate heavy metals, which may lead to contamination of crops at concentrations exceeding permitted levels, which disqualifies them in terms of quality (Safari et al. 2015).

The heavy metals such as cadmium $(\mathrm{Cd})$, lead $(\mathrm{Pb})$, chromium $(\mathrm{Cr})$, copper $(\mathrm{Cu})$, and zinc $(\mathrm{Zn})$ are an important group of trace elements, which in concentrations above the norm can negatively influence the development of people, animals $(\mathrm{Cd}$ and $\mathrm{Pb})$, and plants ( $\mathrm{Zn}$ and Cr) (Castaldi et al. 2009; Safari et al. 2015). Bioaccumulation of microelements in plants causes their inclusion in the food chain: soil-plant-animal-human. Metals occurring in the form of free ions are most easily accumulated from soil by plants. In turn, metals existing in complexes can be released from soil by active substances secreted by plant roots and microorganisms in soil, then easily taken up by plants, thus affecting the growth and quality of yield (Zaccone et al. 2010).

In the literature, there are many reports describing influence of heavy metals on soil degradation in industrial areas (Birkhofer et al. 2008; Castaldi et al. 2009; Singh et al. 2010). According to the best of our knowledge, there is a lack of research studies of agricultural soils and crops where the pesticide was applied and the evaluation of migration of heavy metals in the system soil-plant-grain was conducted.

We hypothesize that fungicides and herbicides may stop or activate migration of the heavy metals into the soil-plant-cereals system as well as they may also influence quality parameters of grain.

Therefore, the novelty of this study was to evaluate the effect of different chemical wheat protective treatments on migration of heavy metals present in the soil enriched with sewage sludge to plants and grains. Additionally, the aims were to evaluate the bioaccumulation factor and to search for the correlation between quantitative and qualitative parameters of wheat and metal content in the grain.

\section{Materials and methods}

The field experiment and weather conditions

The field experiment was conducted in 2014 in Podlaskie ( $53^{\circ} 11^{\prime} 45.2^{\prime \prime} \mathrm{N} 23^{\circ} 00^{\prime} 40.4^{\prime \prime}$ E) using the method of randomized blocks with four replications. Spring wheat was sown on 31.03.2014. Fertilization had been performed before sowing (28.03.2014), using organic fertilizer (N $87.5 \mathrm{~kg} / \mathrm{ha}, \mathrm{P} 133 \mathrm{~kg} / \mathrm{ha}$, organic substance $1400 \mathrm{~kg} / \mathrm{ha}$ ). In addition, on the plots, one used sewage sludge from the local sewage treatment plant. According to Zadoks' scale (Zadoks et al. 1974) in the shooting phase (BBCH 30 ), ammonium nitrate (N $34 \mathrm{~kg} / \mathrm{ha}$ ) was used. 
Meteorological data were collected from the automatic weather station located near the experimental plots $\left(53^{\circ} 11^{\prime} 50.2^{\prime \prime} \mathrm{N} 23^{\circ} 00^{\prime} 41.4^{\prime \prime} \mathrm{E}\right)$. In the conducted experiment, weather conditions were characterized by low rainfall, the sum of which amounted to $25 \mathrm{~mm}$ in April, $94 \mathrm{~mm}$ in May, $72 \mathrm{~mm}$ in June, and $74 \mathrm{~mm}$ in July. The observed amount of rainfall was lower on average by $38 \%$ with respect to rainfall in the same period (April-July) in previous years (2002-2013). Average daily temperatures in April, May, June, and July were respectively $8,14,13$, and $20^{\circ} \mathrm{C}$.

The variants of chemical protection

The following kinds of plots were set: the control plots without chemical protection or manual weed control and the plots where one applied chemical protection using a knapsack compressed air sprayer AP-1/p in five variants (Table 1). The treatments were performed using one herbicide and four fungicides (Table 1). The herbicide (Chwastox Turbo 340SL) composed of two active substances carboxylic acid group (MCPA) and benzoic acid derivatives (dicamba) was treated at tillering phase (scale BBCH 19-23). Fungicidal treatments were repeated twice at an interval of 2 weeks. In the wheat heading stage (BBCH 44-58), protective treatment was made using Topsin M 500SC compounds from the group of benzimidazoles (thiophanate-methyl) and Artea 330EC containing the active substances of triazole (propiconazole and cyproconazole). Fungicide application was performed using Amistar 250SC with active substance from the group of strobilurins (azoxystrobin) and Falcon 460EC with plant protection product consisting of spiroxamine, tebuconazole, and triadimenol in the stages of BBCH 71-77 (Table 1).

Parameters of wheat grain quality

The wheat grain samples from each plot were collected for the determination of protein content (\%), wet gluten content (\%), starch content (\%), and ergosterol content $(\mathrm{kg} / \mathrm{ha})$. All samples were measured with NIR/NIT technology fitted with a sample transport module and standard sample cups with a grain analyzer (InfratecTM 1241, Foss). Moreover, one also determined thousand grain weight (TGW) $(\mathrm{g})$, test weight (TW) $(\mathrm{kg} / \mathrm{hL})$, and Zeleny sedimentation volume $(\mathrm{ZSV})(\mathrm{ml})$ using the AACC method (American Association of Cereal Chemists International, 2000).
Chemical analyses of soil and sewage sludge

Laboratory studies included the determination of the total nitrogen concentrations in soil using the Kjeldahl method after mineralization of samples in concentrated sulfuric acid (Bremner and Mulvaney 1982), organic carbon was measured by the Tiurin method, and the content of total sulfur was determined by the nephelometric method of Butters and Chenery (1959). The values of $\mathrm{pH}$ in soil were measured by $1 \mathrm{M} \mathrm{KCl}$.

Analyses of heavy metals

Metal contents of samples were analyzed in an accredited laboratory, using certified reference materials INCT-MPH2. The samples of the plants $(0.5 \mathrm{~g})$ were digested in a closed microwave system (CEM MARS 5) in $10 \mathrm{ml}$ of $65 \% \mathrm{HNO}_{3}$ (Merck suprapur®). The samples were heated during digestion in two cycles by extending the time, increasing the temperature, and using the microwave oven at a fixed power level $(1600 \mathrm{~W}, 100 \%$ for $5 \mathrm{~min}$, the temperature increased to $135{ }^{\circ} \mathrm{C}$, then for $5 \mathrm{~min}$, it maintained at $135{ }^{\circ} \mathrm{C}$; $1600 \mathrm{~W}, 100 \%$ for $5 \mathrm{~min}$, the temperature increased to $165^{\circ} \mathrm{C}$, then for $20 \mathrm{~min}$, it remained at $165^{\circ} \mathrm{C}$ ). After cooling, the samples were filtrated into 50 -ml volumetric flasks. The total content of metals was analyzed by means of the atomic absorption spectrometry (AAS) by using Varian AA240Z - graphite furnace atomic spectroscopy (GFAAS). The accuracy of the completed mineralization and GFAAS determination was confirmed in the analysis of the certified material INCT-MPH2 (mixture of Polish herbs) - recovery percentage of the reference material was equal to $97.7 \%$. All samples were analyzed in triplicate.

The samples of soils $(0-25 \mathrm{~cm})$ and soils with sewage sludge were collected and the concentrations of $\mathrm{Cd}, \mathrm{Cr}$, $\mathrm{Cu}, \mathrm{Ni}, \mathrm{Pb}$, and $\mathrm{Zn}$ were determined by the AAS by using Thermo Scientific iCE3300. All the samples $(1.0 \mathrm{~g})$ were mineralized by using microwave digestion system and remains were dissolved in aqua regia at $80{ }^{\circ} \mathrm{C}$ in triplicate, according to the Polish norm PNISO 11047:2001. ERM-CD281 reference material was used to evaluate the correctness of the results.

In all analyses, one used water with conductivity $0.05 \mu \mathrm{S} / \mathrm{cm}$ from a Polwater CDRX-200 deionizer. All laboratory vessels used in the experiment were immersed in $10 \% \mathrm{HNO}_{3}$ for $24 \mathrm{~h}$ and then rinsed with deionized water. 
Table 1 The chemical protection variants of spring wheat

\begin{tabular}{|c|c|c|c|c|c|}
\hline Treatment no. & $\begin{array}{l}\text { Variants of the } \\
\text { chemical protection }\end{array}$ & Active substance (a.s.) & Content a.s. (g/l) & Dose $(1 / \mathrm{ha})$ & $\begin{array}{l}\text { Phase of growing } \\
\text { plant } \mathrm{BBCH}^{\mathrm{a}}\end{array}$ \\
\hline 1 & Control & - & - & - & - \\
\hline 2 & $\mathrm{H}$ & $\begin{array}{l}\text { MCPA } \\
\text { Dicamba }\end{array}$ & $\begin{array}{l}300 \\
40\end{array}$ & 2.0 & $21-23$ \\
\hline 3 & $\mathrm{~F} 1$ & $\begin{array}{l}\text { Thiophanate-methyl } \\
\text { Azoxystrobin }\end{array}$ & $\begin{array}{l}500 \\
250\end{array}$ & $\begin{array}{l}1.4 \\
0.8\end{array}$ & $\begin{array}{l}56-58 \\
71-73\end{array}$ \\
\hline 4 & $\mathrm{H}$ & $\begin{array}{l}\text { MCPA } \\
\text { Dicamba }\end{array}$ & $\begin{array}{l}300 \\
40\end{array}$ & 2.0 & $21-23$ \\
\hline & F1 & $\begin{array}{l}\text { Thiophanate-methyl } \\
\text { Azoxystrobin }\end{array}$ & $\begin{array}{l}500 \\
250\end{array}$ & $\begin{array}{l}1.4 \\
0.8\end{array}$ & $\begin{array}{l}56-58 \\
71-73\end{array}$ \\
\hline 5 & $\mathrm{~F} 2$ & $\begin{array}{l}\text { Propiconazole } \\
\text { Cyproconazole } \\
\text { Spiroxamine } \\
\text { Tebuconazole } \\
\text { Triadimenol }\end{array}$ & $\begin{array}{l}250 \\
80 \\
250 \\
167 \\
43\end{array}$ & $\begin{array}{l}0.5 \\
0.6\end{array}$ & $\begin{array}{l}56-58 \\
71-73\end{array}$ \\
\hline 6 & $\mathrm{H}$ & $\begin{array}{l}\text { MCPA } \\
\text { Dicamba }\end{array}$ & $\begin{array}{l}300 \\
40\end{array}$ & 2.0 & $21-23$ \\
\hline & $\mathrm{F} 2$ & $\begin{array}{l}\text { Propiconazole } \\
\text { Cyproconazole } \\
\text { Spiroxamine } \\
\text { Tebuconazole } \\
\text { Triadimenol }\end{array}$ & $\begin{array}{l}250 \\
80 \\
250 \\
167 \\
43\end{array}$ & $\begin{array}{l}0.5 \\
0.6\end{array}$ & $\begin{array}{l}56-58 \\
71-73\end{array}$ \\
\hline
\end{tabular}

$H$ herbicide, $F 1$ first set of fungicides, $F 2$ second set of fungicides

${ }^{\mathrm{a}} \mathrm{BBCH}$ according to (Zadoks et al. 1974)

Parameters of sewage sludge applied in the field experiment

The sludge was dried at $130{ }^{\circ} \mathrm{C}$ and formed in granules. It did not contain Salmonella or invasive nematode ova and was applied on the experimental plots at a dose of $3 \mathrm{~kg} / \mathrm{ha}$ D.M. The concentration of heavy metals of sewage sludge is presented in Table 2. The sewage sludge used in the experiment had $\mathrm{pH}-7.5$ and contained the following: dry matter $89 \%$, organic matter $56.2 \mathrm{~g} / \mathrm{kg}$ D.M., total N $4.6 \%$ D.M., ammonium N $0.32 \%$ D.M., total P $3.2 \%$ D.M., Mg $0.72 \%$ D.M., and Ca $4.16 \%$ D.M.

\section{Bioconcentration factor}

The biological concentration factor (BCF) as given by Arnot and Gobas (2006) and Alam et al. (2003) for analyzed heavy metals was determined as quotients of average concentration of a given element in plants with relation to its average concentration in soil and was defined as

$\mathrm{BCF}=C_{\text {plant }} / C_{\text {soil }}$ where

$C_{\text {plant }}$ - total concentration of heavy metals in the above ground parts of plants in $\mathrm{mg} / \mathrm{kg}$ D.M.

$C_{\text {soil }}$-total concentration of heavy metals in soil

$$
\text { in } \mathrm{mg} / \mathrm{kg} \text { D.M. }
$$

Statistical analysis

The statistical analysis was performed by Statistica 13 . The correlation between heavy metal concentration in the above ground parts of plants and in soil fertilized with sewage sludge was calculated using Spearman's correlation factor $r$ for $p \leq 0.05$. Moreover, the results obtained for grain and plants were calculated statistically by means of variance analysis and the relevant differences were evaluated by Tukey's test, on the relevance level of $\alpha=0.05$. 
Table 2 The experiment and normative values of concentration of heavy metals of sewage sludge used in agriculture purposes

\begin{tabular}{lll}
\hline $\begin{array}{l}\text { Heavy } \\
\text { metal }\end{array}$ & $\begin{array}{l}\text { Experimental } \\
\text { concentration } \\
\text { (mg/kg D.M.) }\end{array}$ & $\begin{array}{l}\text { Normative } \\
\text { concentration }\end{array}$ \\
\hline $\mathrm{Pb}$ & 21.9 & 750 \\
$\mathrm{Cd}$ & 1.2 & 20 \\
$\mathrm{Cu}$ & 208 & 1000 \\
$\mathrm{Cr}$ & 64.3 & 500 \\
$\mathrm{Ni}$ & 30.01 & 300 \\
$\mathrm{Zn}$ & 1100 & 2500 \\
\hline
\end{tabular}

D.M. dry matter

\section{Results and discussion}

The influence of sewage sludge on parameters of soil

In this study, sewage sludge was applied to cereal crops as an alternative source of nutrients necessary for proper development of plants. The applied sewage sludge influenced the parameters of the soil where wheat was sown and different variants of chemical protection were applied. Table 3 shows physical and chemical parameters of the soil prior to the application and enrichment of sludge treatment.

One analyzed heavy metal concentration in the soils before the experiment determining the contents of $\mathrm{Zn}$, $\mathrm{Cd}, \mathrm{Ni}, \mathrm{Cu}, \mathrm{Pb}$, and $\mathrm{Cr}$ under the geochemical background. According to Lis and Pasieczna 1995, the natural content of heavy metals in soil in comparison with the geochemical background was $\mathrm{Cr} 5-10 \mathrm{mg} / \mathrm{kg}$ (8.2), $\mathrm{Cu} 20-40 \mathrm{mg} / \mathrm{kg}$ (6.7), $\mathrm{Ni}<5 \mathrm{mg} / \mathrm{kg}$ (nd), $\mathrm{Cd}$ $<0.5 \mathrm{mg} / \mathrm{kg}$ (0.13), $\mathrm{Pb} 12.5-100 \mathrm{mg} / \mathrm{kg}$ (8.59), and $\mathrm{Zn}$ $25-400 \mathrm{mg} / \mathrm{kg}$ (24.0) (the average values of the individual heavy metal accumulation in the experimental soil before application sewage sludge given in parentheses).
According to the actual appropriate The Directive of Environmental Minister on municipal sewage sludge (J. of Laws, 2015, item. 257), the tested sludge, soil enriched with granular sludge and soil samples taken from the top layer of plots $(0-25 \mathrm{~cm})$ met these official criteria (Table 3).

The dynamics of changes in metal forms is most intense at the top layer of soil. It depends on the diverse population of microorganisms, organic matter content, the sorption capacity, biological interactions of microorganisms of the rhizosphere as well as the plant itself, and protective treatments performed (Walker et al. 2004). Metal accumulation in soil and their availability to plants are also determined by the $\mathrm{pH}$ of the soil. In our study, the $\mathrm{pH}$ ranged from 6.6 to 7.4, so the soil and heavy metals contained in it should not be a major threat to plants and the environment and therefore should not go into the food chain (Wołejko et al. 2014; Yoneyama et al. 2010). Moreover, Wang et al. (2006) claim that metal solubility is conditioned by the exchange sorption processes and it is low for neutral and alkaline reactions. In turn, as reported by Tarek and Shehata (2015), during growth of plants and root development, roots emit into the soil organic acids which may make heavy metal solubility more intensive and influence absorption through the root system. It is confirmed by own research, as in the grain collected from the control plots where the $\mathrm{pH}$ was neutral, one observed slightly exceeded lead content in comparison with the allowed given in the Commission Regulation (EU) No. $1881 / 2006$. Whereas, according to Merrington and Smernik (2004), increasing soil $\mathrm{pH}$ by adding sewage sludge may also result in the releasing of some metals such as $\mathrm{Cr}$ from the soil and causing oxidation of $\mathrm{Cr}^{3+}$ to a more mobile and toxic $\mathrm{Cr}^{6+}$, which is taken up by plants and can go into the food chain (Sivakumar and Subbhuraam 2005).

Table 3 Selected chemical properties of soil before and after application of sludge

\begin{tabular}{|c|c|c|c|c|c|c|c|c|c|c|}
\hline & $\mathrm{pH}$ & $\begin{array}{l}\mathrm{N} \\
(\% \mathrm{D}\end{array}$ & $\mathrm{C}$ & $\mathrm{S}$ & $\begin{array}{l}\mathrm{Cu} \\
(\mathrm{mg} \\
\mathrm{D} . \mathrm{M}\end{array}$ & $\mathrm{Zn}$ & $\mathrm{Pb}$ & $\mathrm{Cd}$ & $\mathrm{Cr}$ & $\mathrm{Ni}$ \\
\hline Control soil (without sewage sludge) & $6.6-7.0$ & 0.15 & 1.45 & 0.026 & 6.7 & 24.0 & 8.59 & 0.13 & 8.2 & nd \\
\hline Soil enriched in sewage sludge & $7.2-7.4$ & 1.50 & 3.75 & 25.21 & 32 & 86.14 & 18.94 & 0.81 & 42.3 & 5.89 \\
\hline $\begin{array}{l}\text { Normative maximum limit of content } \\
\text { heavy metals in soil }\end{array}$ & - & - & - & - & 50 & 120 & 60 & 2 & 75 & 35 \\
\hline
\end{tabular}

nd not detected, D.M. dry matter 
Influence of chemical treatments on migration of metals in plant and wheat grains

The results shown in Fig. 1 indicate that the application of the six variants of protection treatments influenced the migration of different heavy metals from the soil to plants. Defending themselves against poisoning by heavy metals, plants evolved defense mechanisms allowing them to grow and develop in contaminated
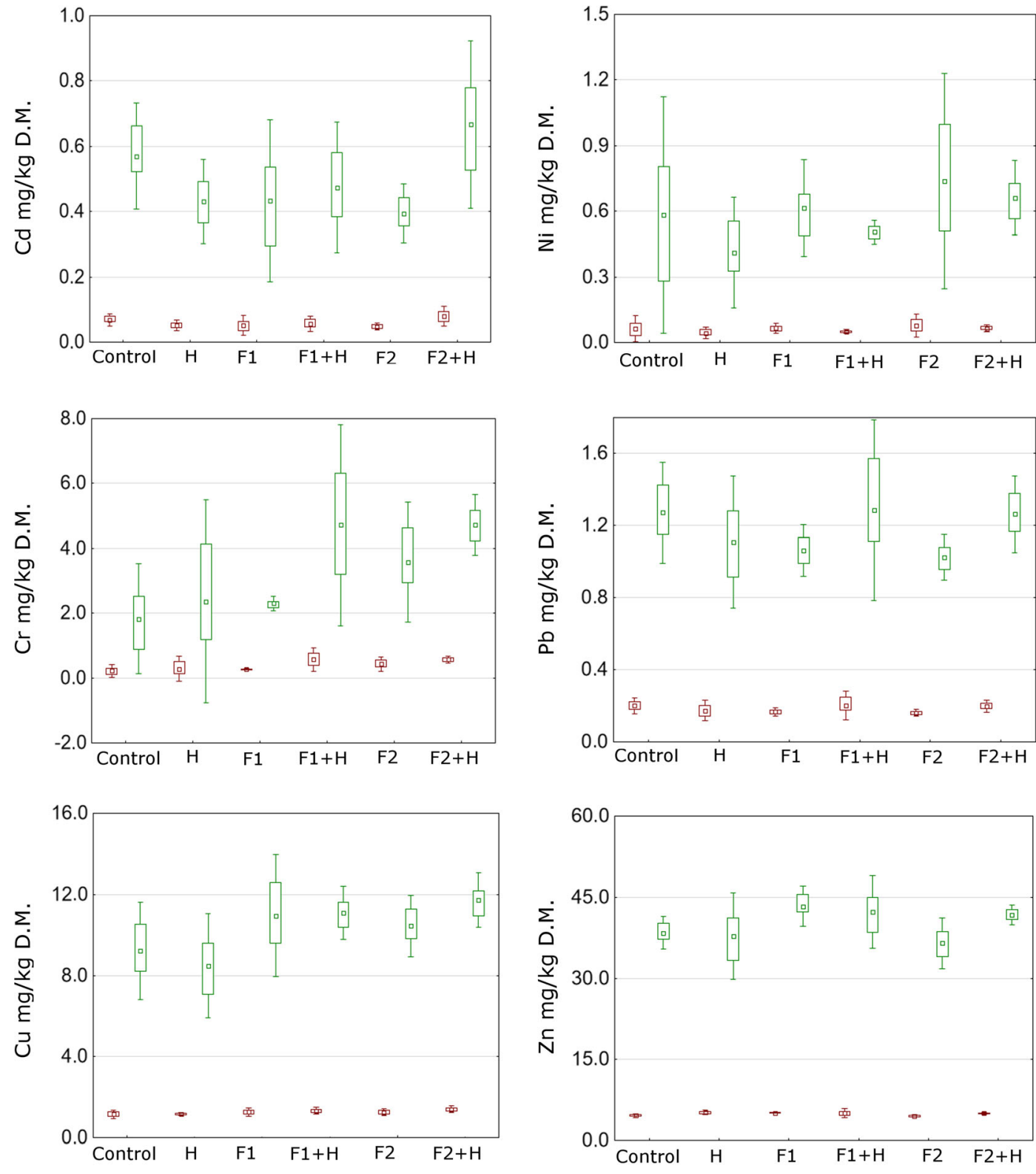

- Mean $\square$ Min-Max I Mean $\pm 2 *$ Odch.std घ grain @plant

Fig. 1 Metal concentration (mg/kg D.M.) in plant and wheat grains depending on the applied plant protection treatment 
lowest was observed at the applied fungicide treatment F2 in leaves 0.39 and $0.047 \mathrm{mg} / \mathrm{kg}$ D.M. in wheat grains (Fig. 1, Table 4). Cadmium content in wheat grain was within the exposure limit values according to which the maximum level for $\mathrm{Cd}$ is $0.10 \mathrm{mg} / \mathrm{kg}$ D.M. (EU 1881/2006). Yoneyama et al. (2010) reported that some metals including cadmium can be absorbed by the clay minerals in the soil, thus lowering the concentration of metals in dissolved form and reducing the absorption of this element by plants (Merrington and Smernik 2004). Furthermore, as suggested by Zaccone et al. (2010), cadmium in the grain is distributed evenly and after elimination of bran, it remains in the flour in the same proportion as it appeared in the grain, thus threatening the health of animals and humans. It may induce small skeletal damage, kidney dysfunction symptoms, and reproductive deficiencies.

As observed by Garcia-Delgado et al. (2007), chromium is taken up by plants by passive transport because the plants do not accumulate chromium, even if it is present in large quantities, but in the environment, the concentrations of chromium is steadily increasing which is a matter of concern (Bielicka et al. 2005). In our study, the average chromium content ranged from 0.89 to $6.31 \mathrm{mg} / \mathrm{kg}$ D.M. in wheat leaves and from 0.11 to $0.76 \mathrm{mg} / \mathrm{kg}$ D.M. for wheat grains. Applied plant protection treatments significantly affected the absorption of $\mathrm{Cr}$ by wheat (Fig. 1, Table 4); the largest quantities of $\mathrm{Cr}$ were taken by plants growing on plots $\mathrm{F} 1+\mathrm{H}$ and $\mathrm{F} 2$ $+\mathrm{H}$, while the smallest amount was determined in the samples from the control plots.

Copper belongs to metals necessary for the proper conduct of some processes like the formation of proteins, photosynthesis, respiration, or the transformation of nitrogen compounds and permeability of cell membranes (Miotto et al. 2014). Based on these results, one observed that the highest statistically significant copper content occurred on the plots where treatments F1 and $\mathrm{F} 2+\mathrm{H}$ were applied, while the smallest $\mathrm{Cu}$ was observed in plants collected from the plots where one applied only herbicide treatment $(\mathrm{H})$ and this amount was lower by $8 \%$ compared with control plots. The average copper content ranged from 7.08 to $12.59 \mathrm{mg} / \mathrm{kg}$ D.M. in wheat leaves and from 1.06 to $1.46 \mathrm{mg} / \mathrm{kg}$ D.M. for wheat grains (Fig. 1, Table 4). Yruela (2005) points out that in soils, copper occurs in various forms, usually forming combinations of little mobility in the form of precipitates of carbonate and sulfate. Despite the low mobility, copper is easily absorbed by plants, thus resulting in the inhibition of enzyme activity or protein function, as well as a deficit of other essential ions through the disturbance of the cell transport (Yruela 2005; Wuana and Okieimen 2011).

In our study, one observed different contents of nickel in plants, depending on the plant protection treatment. The highest amount of nickel was taken by the plants from the plots with F2 fungicide treatment and from the plots where one applied MCPA and 2,4-D (H). The content of $\mathrm{Ni}$ in plants and grain was low and amounted to respectively 0.41 and $0.04 \mathrm{mg} / \mathrm{kg}$ D.M. (Fig. 1, Table 4). The average nickel concentration was in the range from 0.32 to $0.99 \mathrm{mg} / \mathrm{kg}$ D.M. in wheat leaves and from 0.04 to $0.11 \mathrm{mg} / \mathrm{kg}$ D.M. for wheat grains. Nickel, like copper and manganese, belongs to important micronutrients influencing plants' growth and development, but at high concentrations, it is toxic and can affect the permeability of the membrane, inhibit sprouting, and limit the growth and development of plants, thus affecting yield reduction (Boominathan and Doran 2002). At the low $\mathrm{pH}$, the bond strength of nickel by soil organic matter is small, and at the neutral $\mathrm{pH}$, the bond is very strong, which is relevant to the bioavailability of this metal (Sanz et al. 2009).

Lead belongs to the elements strongly bound in the soil and accumulated at the humus level. After

Table 4 Analysis of variance between concentration of each metal in plant/grain and chemical treatment (statistically significant for the $\alpha=0.05$ )

\begin{tabular}{lllllll}
\hline & $\mathrm{Cd}$ & $\mathrm{Cr}$ & $\mathrm{Cu}$ & $\mathrm{Ni}$ & $\mathrm{Pb}$ & $\mathrm{Zn}$ \\
\hline Grain & & & & & & \\
Control & 0.068 & 0.219 & 1.149 & 0.063 & 0.201 & 4.605 \\
$\mathrm{H}$ & 0.052 & 0.284 & 1.154 & 0.044 & 0.175 & 5.167 \\
F1 & 0.052 & 0.276 & 1.259 & 0.066 & 0.168 & 5.093 \\
F1 + H & 0.057 & 0.565 & 1.331 & 0.051 & 0.203 & 5.076 \\
F2 & 0.047 & 0.429 & 1.253 & 0.079 & 0.162 & 4.559 \\
F2 + H & 0.080 & 0.565 & 1.405 & 0.065 & 0.199 & 5.003 \\
NIR & 0.025 & 0.321 & 0.144 & $\mathrm{~ns}$ & $\mathrm{~ns}$ & 0.501 \\
Plant & & & & & & \\
Control & 0.569 & 1.829 & 9.211 & 0.584 & 1.272 & 38.405 \\
H & 0.431 & 2.366 & 8.485 & 0.411 & 1.109 & 37.811 \\
F1 & 0.434 & 2.300 & 10.948 & 0.616 & 1.061 & 43.328 \\
F1 + H & 0.474 & 4.715 & 11.098 & 0.504 & 1.285 & 42.333 \\
F2 & 0.394 & 3.574 & 10.449 & 0.737 & 1.024 & 36.474 \\
F2 + H & 0.667 & 4.715 & 11.714 & 0.661 & 1.263 & 41.725 \\
NIR & 0.207 & 2.677 & 2.281 & ns & ns & ns \\
\hline
\end{tabular}

ns non-significant 
mixing the sludge with the soil, it is subject to sorption by the oxides and hydroxides of $\mathrm{Fe}$ and $\mathrm{Mn}$, and organic matter. In the soil environment, it migrates less actively than zinc or cadmium, but like these elements, it is readily taken up by plants (Kabata Pendias and Pendias 2001; Wuana and Okieimen 2011). In our study, the lead content ranged from 0.92 to $1.57 \mathrm{mg} / \mathrm{kg}$ D.M. in wheat leaves and from 0.14 to $0.25 \mathrm{mg} / \mathrm{kg}$ D.M. for wheat grains. Fungicidal treatments such as F1 and F2 caused less migration of lead in the soil by the plant and thus lowered the migration of this element to the grain (Fig. 1). $\mathrm{Pb}$ content in the grain was the highest on the control plots and $\mathrm{F} 1+\mathrm{H}$, respectively, 0.21 and $0.25 \mathrm{mg} / \mathrm{kg}$ D.M. The obtained values were above the limits for concentration of the maximum level $0.20 \mathrm{mg} / \mathrm{kg}$ D.M. described in the Commission Regulation (EU) No. 1881/2006, and the grain from the plots should not be directed at consumption targets and feed. However, according to Zaccone et al. (2010), lead in cereal grains is localized mainly in the outer layer, and it is eliminated during the process of milling grain to obtain flour (Safari et al. 2015).

According to Zhao et al. (2001), on the soil enriched with sludge, there is an increase of activity of microorganisms in the rhizosphere zone which may lead to an increased solubility of $\mathrm{Zn}$ and hence greater absorption of this element by the plants. In our study, plant protection treatments had a significant influence on the zinc content in aboveground parts of spring wheat. The content of $\mathrm{Zn}$ ranged from 33 to $45 \mathrm{mg} / \mathrm{kg}$ D.M. in wheat leaves and from 0.03 to $0.11 \mathrm{mg} / \mathrm{kg}$ D.M. for wheat grains. The largest amount of $\mathrm{Zn}$ was taken up by the plants from the plots where one applied fungicidal treatments $\mathrm{F} 1$ and $\mathrm{F} 1+\mathrm{H}$, which influenced the content of $\mathrm{Zn}$ in grain and plants. Their values were higher by approximately 10 and $12 \%$, respectively, in comparison with the control plots (Fig. 1). The zinc belongs to metals, which can be accumulated in the plants, even in large amounts (above 1\%) with no apparent signs of toxic effects. It is also worth noting that grass plants which also include grain are the most susceptible to deficiency of this nutrient. Deficiency of this element impairs the synthesis of tryptophan, which in turn can lead to the inhibition of plant growth and influence the final yield (Wuana and Okieimen 2011; Impa et al. 2013).

The statistical analysis revealed correlations between metal concentration in the soil and their concentration in the plants' aboveground parts. Nickel in the soil was correlated with $\mathrm{Cd}(r=0.33), \mathrm{Zn}(r=0.45)$, and $\mathrm{Cu}$ $(r=0.39)$ in plants, and the $\mathrm{Cr}$ content in the soil was significantly correlated with the level $\mathrm{Pb}(r=0.46)$ in plants. A positive correlation between the metals showed that all the analyzed metals were taken up by plants from the soil solution in a similar way, which could have a significant influence on plant growth and crop quality.

Bioconcentration factor for heavy metal in wheat cereals

In our study, the calculated value of the BCF allowed for evaluating the ability of wheat to collect heavy metals present in the soil and determine the rate and the migration of metals from the soil solution containing sludge to the aerial parts of wheat depending on the chemical protection variant (Fig. 2). Moreover, the metals' presence and their toxicity will largely depend on the functions which then perform in the metabolic processes in the organism and susceptibility of the plants to bioaccumulation (Bose and Bhattacharyya 2008).

In the present research experiment, one observed the effect of the applied protective operation on the rate of bioaccumulation. The lowest rate of bioaccumulation for all the analyzed metals was found on the plots with fungicide treatments $\mathrm{F} 1$ and $\mathrm{F} 2$, while the highest $\mathrm{BFC}$ on the control plots and herbicide treatments (Fig. 2). The bioconcentration factor for zinc, copper, and lead fluctuated at a similar level (respectively, $\mathrm{BCF}=0.44$, $\mathrm{BCF}=0.12$, and $\mathrm{BCF}=0.07$ ) for almost all plots regardless of the variant of used plant protection

Bioconcentration factor

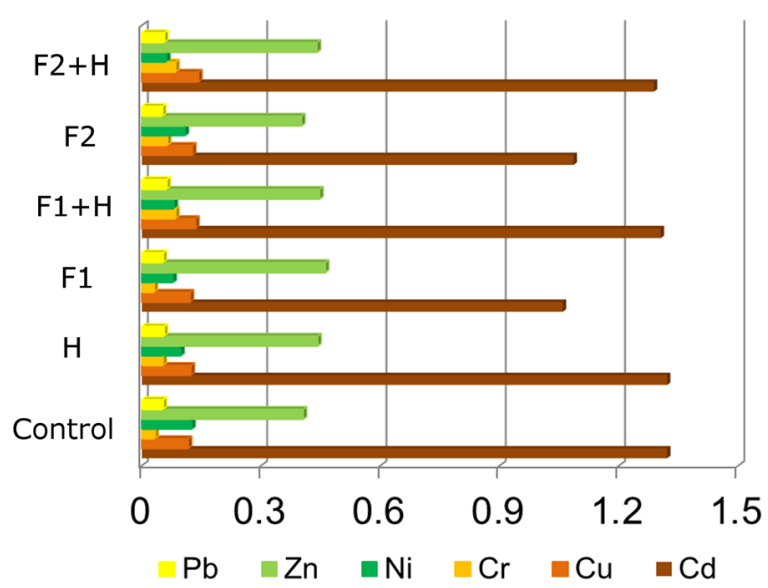

Fig. 2 Bioconcentration factor for heavy metals $(\mathrm{Ni}, \mathrm{Cu}, \mathrm{Cr}, \mathrm{Cd}$, $\mathrm{Pb}$, and $\mathrm{Zn}$ ) in wheat depending on the plant protection treatment 
products. Soil $\mathrm{pH}$ also has influence on the bioconcentration of $\mathrm{Zn}$ and $\mathrm{Cu}$, since it decreases with increasing $\mathrm{pH}$ of soil solubility (Wuana and Okieimen 2011; Wołejko et al. 2013). However, the anionic complex connections of organic mineral exhibit high mobility as an alkaline medium which may also affect the bioconcentration of these metals in plants (Arnot and Gobas 2006). In addition, the highest rate of bioconcentration observed for cadmium in the control plots, with $\mathrm{H}$ and $\mathrm{F} 1+\mathrm{H}$ and $\mathrm{F} 2+\mathrm{H}$, was 1.3. Wuana and Okieimen (2011) reported that the rate of bioaccumulation of various heavy metals, especially cadmium, is characterized by high species variety and even varietal diversity. Although cadmium is not necessary for plant development, it is absorbed very easily, both through the roots and leaves, generally in proportion to the concentration in the environment (Gill and Tuteja 2011). It is also important to know biochemicals changes in the vicinity of the roots, because they affect the transfer of metal ions to plants and living organisms (Martin et al. 2004).

The influence of heavy metals on the parameters of wheat quality

The yield of cereals depends largely on the smooth process of photosynthesis and distribution of assimilates during the growing season, which plays a key role in supplying the plant with macro- and micronutrients (Aliyev 2012). Table 5 shows the effect of fungicideherbicide treatments on the quality parameters of spring wheat grain. The methods used to protect plants caused a slight increase of the protein and gluten content. The sedimentation index was slightly higher as compared with controls. An important indicator of the size and quality of the wheat crop is the number of ears per unit area and the number of grains per spike (Stagnari et al. 2013). In our study, one used treatment $\mathrm{H}, \mathrm{F} 1+\mathrm{H}$, and $\mathrm{F} 2+\mathrm{H}$ which contributed to the increase in yield, number of grains per spike, and ears per unit area. In addition, the highest values were observed for thousand grain weight and test weight with the applied treatments $\mathrm{F} 1$ and $\mathrm{F} 1+\mathrm{H}$ (Table 5).

Table 6 presents the analysis of the Spearman rang correlation of various metal concentrations in grain and grain quality parameters of spring wheat. The statistical analysis showed a significant correlation between the metals contained in grain and the quality parameters of wheat grain. The total content of $\mathrm{Cu}$ in grains was positively correlated with the protein and gluten content as well as with the sedimentation value (respectively, $r=0.49, r=0.50, r=0.57$ ). Positive correlations were observed between $\mathrm{Cd}$ and the yield, the number of grains and ergosterol content (respectively, $r=0.41$, $r=0.55, r=0.56$ ), and $\mathrm{Zn}$ with thousand grain weight $(r=0.50)$ at a $p \leq 0.05$. Positive correlation between these elements in grain and grain quality parameters suggests that each of these metals may influence grain quality parameters. Both $\mathrm{Zn}$ and $\mathrm{Cu}$ are elements essential for proper plant growth and development. The appropriate contents of these trace elements may positively influence the accumulation in the grain components such as the protein and gluten content as well as the sedimentation value. In turn, $\mathrm{Cd}$ is not needed by plants for their development; however, in case of small concentration, no harmful effects on plant growth and development are observed.

Statistically significant negative correlations were obtained between $\mathrm{Ni}$ and the sedimentation value

Table 5 Effect of different variants of chemical treatments on the quality parameters of spring wheat grain

\begin{tabular}{lllllllllll}
\hline & NS & NG/S & TGW & GY & TW & GPC & WGC & SC & ZSV & EC \\
\hline C & 213.41 & 4712.67 & 36.94 & 4.60 & 74.07 & 9.65 & 18.13 & 72.68 & 23.19 & 3.03 \\
H & 220.25 & 5037.42 & 36.56 & 4.80 & 73.14 & 10.08 & 19.28 & 72.43 & 25.23 & 2.81 \\
F1 & 199.92 & 4485.58 & 39.70 & 4.63 & 76.23 & 9.70 & 18.25 & 72.59 & 23.91 & 2.45 \\
F1 + H & 214.00 & 4879.08 & 40.25 & 5.05 & 76.23 & 10.11 & 19.38 & 72.44 & 25.82 & 2.57 \\
F2 & 196.58 & 4367.75 & 38.62 & 4.52 & 73.72 & 9.81 & 18.55 & 72.57 & 23.96 & 2.73 \\
F2 + H & 210.25 & 4950.08 & 38.35 & 4.92 & 72.81 & 9.87 & 18.64 & 72.65 & 24.16 & 2.66 \\
\hline
\end{tabular}

$C$ control, $N S$ number of spike, $N G / S$ number of grains per spike, $G Y$ yield (t/ha), $T G W$ thousand grain weight (g), $S C$ starch content (\%), $G P C$ grain protein content (\%), EC ergosterol content (mg/kg), WGC wet gluten content (\%), ZSV Zeleny sedimentation value (ml), $T W$ test weight $(\mathrm{kg} / \mathrm{hl})$ 
Table 6 Spearman's rang correlation analysis concentrations of metal in grain versus grain quality parameters in spring wheat

\begin{tabular}{lclllll}
\hline & $\mathrm{Ni}$ & $\mathrm{Cd}$ & $\mathrm{Cu}$ & $\mathrm{Zn}$ & $\mathrm{Pb}$ & $\mathrm{Cr}$ \\
\hline $\mathrm{NS}$ & -0.29 & 0.38 & 0.35 & 0.09 & 0.34 & 0.36 \\
$\mathrm{NG} / \mathrm{S}$ & -0.13 & $0.55^{*}$ & 0.26 & 0.34 & -0.02 & 0.38 \\
$\mathrm{TGW}$ & -0.14 & 0.02 & 0.13 & $0.50^{*}$ & -0.22 & 0.21 \\
$\mathrm{GY}$ & -0.09 & $0.41^{*}$ & 0.19 & 0.41 & -0.17 & 0.32 \\
$\mathrm{TW}$ & -0.28 & -0.06 & 0.28 & 0.03 & 0.38 & 0.24 \\
GPC & -0.39 & 0.05 & $0.49^{*}$ & 0.01 & 0.34 & 0.39 \\
WGC & -0.38 & 0.11 & $0.50^{*}$ & 0.07 & 0.22 & 0.39 \\
SC & 0.36 & 0.20 & -0.40 & 0.24 & $-0.57^{*}$ & -0.24 \\
ZSV & $-0.51^{*}$ & 0.08 & $0.57^{*}$ & -0.09 & 0.46 & 0.41 \\
EC & 0.06 & $0.56^{*}$ & 0.10 & -0.16 & -0.16 & 0.12 \\
\hline
\end{tabular}

$N S$ number of spike, $N G / S$ number of grains per spike, $G Y$ yield (t/ha), $T G W$ thousand grain weight $(\mathrm{g}), S C$ starch content (\%), $G P C$ grain protein content $(\%), E C$ ergosterol content $(\mathrm{mg} / \mathrm{kg})$, $W G C$ wet gluten content (\%), ZSV Zeleny sedimentation value (ml), $T W$ test weight $(\mathrm{kg} / \mathrm{hl})$

*Significant correlations for $p<0.05$

$(r=-0.51)$ and between $\mathrm{Pb}$ and the starch content in the grain $(r=-0.57)$ at a $p \leq 0.05$. In our studies, the lead concentration in grains was above the allowed norms, so the high amount of this metal may adversely affect the grain quality parameters including starch content.

\section{Conclusions}

1. The concentrations of heavy metals in wheat leaves and grains depended on variants of chemical protection.

2. Protection treatments with fungicide and herbicide conducted during the growing season did not result in exceeding the allowed concentration of cadmium in wheat grain.

3. In the grains from the plots protected with the combination $\mathrm{F} 1+\mathrm{H}$, lead content exceeded the maximum levels; it can migrate in the system soilplant-cereals and be absorbed more easily.

4. The bioconcentration factor for individual metals was dependent on the type of protective treatments and it was the highest for cadmium. This confirmed its high mobility and the possibility of its adverse influence on quality of the final yield.

5. Occurring in soil with sewage sludge, metals significantly affect the qualitative and quantitative parameters of spring wheat.
Acknowledgements The research is financially supported by project number S/WBiIŚ/3/2015 and by the Polish Ministry of Science and Higher Education, project ID: SBI-09 "Biology, harmfulness and methods for reducing cereal diseases caused by fungi in the north-eastern Poland." The authors are grateful to Ms. Krystyna Snarska for the technical assistance in field experiment.

\section{Compliance with ethical standards}

Conflict of interest The authors declare that they have no conflict of interest.

Open Access This article is distributed under the terms of the Creative Commons Attribution 4.0 International License (http:// creativecommons.org/licenses/by/4.0/), which permits unrestricted use, distribution, and reproduction in any medium, provided you give appropriate credit to the original author(s) and the source, provide a link to the Creative Commons license, and indicate if changes were made.

\section{References}

AACC International (2000). Approved Methods of the American Association of Cereal Chemists, Cereal Laboratory Methods, 10th ed. AACC International, St. Paul MN, USA, Method 55-10: Test Weight.

Alam, M. G. M., Snow, E. T., \& Tanaka, A. (2003). Arsenic and heavy metal contamination of vegetables grown in Santa village, Bangladesh. Science of the Total Environment, 308, 83-96. doi:10.1016/S0048-9697 (02)00651-4.

Aliyev, J. A. (2012). Photosynthesis, photorespiration and productivity of wheat and soybean genotypes. Physiologia Plantarum, 145, 369-383. doi:10.1111/j.1399-3054.2012.01613.x.

Arnot, J. A., \& Gobas, A. P. C. (2006). A review of bioconcentration factor (BCF) and bioaccumulation factor (BAF) assessments for organic chemicals in aquatic organisms. Environmental Reviews, 14(4), 257-297. doi:10.1139/a06-005.

Balba, H. (2007). Review of strobilurin fungicide chemicals. Journal of Environmental Science and Health, Part B, 42(4), 441-451. doi:10.1080/03601230701316465.

Bielicka, A., Bojanowska, I., \& Wiśniewski, A. (2005). Two faces of chromium - pollutant and bioelement. Polish Journal of Environmental Studies, 14(1), 5-10.

Birkhofer, K., Bezemer, T. M., Bloem, J., Bonkowski, M., Christensen, S., Dubois, D., et al. (2008). Long-term organic farming fosters below and aboveground biota: implications for soil quality, biological control and productivity. Soil Biology and Biochemistry, 40, 2297-2308. doi:10.1016/j.soilbio.2008.05.007.

Bjorling-Poulsen, M., Andersen, H. R., \& Grandjean, P. (2008). Potential developmental neurotoxicity of pesticides used in Europe. Environmental Health, 7, 1-22. doi:10.1186/1476069X-7-50.

Boominathan, R., \& Doran, P. M. (2002). Ni-induced oxidative stress in roots of the Ni hyperaccumulator, Alyssum bertolonii. New Phytologist, 156, 205-215. doi:10.1046 j.1469-8137.2002.00506.x.

Bose, S., \& Bhattacharyya, A. K. (2008). Heavy metal accumulation in wheat plant grown in soil amended with industrial 
sludge. Chemosphere, 70, 1264-1272. doi:10.1016/j. chemosphere.2007.07.062.

Bremner, J. M., \& Mulvaney, C. S. (1982). Nitrogen-total. Methods of soil analysis. Part 2, chemical and microbiological. The Soil Science Society of America, 9(2), 595-624. doi:10.2134/agronmonogr9.2.2ed.c31.

Butters, B., \& Chenery, E. M. (1959). A rapid method for determination of the total sulphur in soils and plants. Analist, 84, 239-245. doi:10.1039/AN9598400239.

Castaldi, P., Melis, P., Silvetti, M., Deiana, P., \& Garau, G. (2009). Influence of pea and wheat growth on $\mathrm{Pb}, \mathrm{Cd}$, and $\mathrm{Zn}$ mobility and soil biological status in a polluted amended soil. Geoderma, 151, 241-248. doi:10.1016/j.geoderma.2009.04.009.

Cobbett, C. S. (2000). Phytochelatins and their roles in heavy metal detoxification. Plant Physiology, 123, 825-832. doi:10.1104/pp.123.3.825.

Commission Regulation (EC) No 1881/2006 of 19 December. (2006). Setting maximum levels for certain contaminants in foodstuffs. (in Polish) http://eur-lex.europa.eu/legalcontent/EN/ALL/?uri=CELEX\%3A32006R1881. Accessed 25 June 2016.

Directive of Environmental Minister of February 6th. (2015). Concerning municipal sewage sludges (J. of Laws, 2015, item 257) (in Polish). http://dziennikustaw.gov.pl/du/2015 /257/1. Accessed 15 June 2016.

Garcia-Delgado, M., Rodriguez-Cruz, M. S., Lorenzo, L. F., Arienz, o. M., \& San-Chez-Martin, M. J. (2007). Seasonal and time variability of heavy metal content and of its chemical forms in sewage sludges from different wastewater treatment plants. Science of the Total Environment, 382, 82-92. doi:10.1016/j.scitotenv.2007.04.009.

Gill, S. S., \& Tuteja, N. (2011). Cadmium stress tolerance in crop plants. Plant Signaling Behavior, 6(2), 215-222. doi:10.4161 /psb.6.2.14880.

Impa, S. M., Gramlich, A., Tandy, S., Schulin, R., Frossard, E., \& Johnson-Beebout, S. E. (2013). Internal Zn allocation influences $\mathrm{Zn}$ deficiency tolerance and grain $\mathrm{Zn}$ loading in rice (Oryza sativa L.) Frontiers in Plant Science, 4, 534. doi:10.3389/fpls.2013.00534.

Jabłońska-Trypuć, A., Wołejko, E., Wydro, U., \& Butarewicz, A. (2017). The impact of pesticides on oxidative stress level in human organism and their activity as an endocrine disruptor. Journal of Environmental Science and Health, Part B, 1-12. doi:10.1080/03601234.2017.1303322 [Epub ahead of print].

Kabata Pendias, A., \& Pendias, H. (2001). Trace elements in soils and plants (3rd ed.). Boca Raton, FL: CRC Press.

Ławniczak, Ł., Syguda, A., Borkowski, A., Cyplik, P., Marcinkowska, K., Wolko, Ł., Praczyk, T., Chrzanowski, Ł., \& Pernak, J. (2016). Influence of oligomeric herbicidal ionic liquids with MCPA and Dicamba anions on the community structure of autochthonic bacteria present in agricultural soil. Science of the Total Environment, 563-564, 247255. doi:10.1016/j.scitotenv.2016.04.109.

Lis, J., \& Pasieczna, A. (1995). The geochemical atlases of Poland 1:2 500 000. Warszawa: Polish Geological Institute National Research Institute.

Łozowicka, B., Miciński, J., Zwierzchowski, G., Kowalski, I. M., \& Szafarek, J. (2012). Cereal grain and feed material containing residues of plant protection chemicals and their effects on human and animal health. Polish Journal of Environmental Studies, 21(6), 181-190.
Łozowicka, B., Wołejko, E., \& Konecki, R. (2016). Influence of selected active substances of fungicides and herbicides and time of their application on chlorophyll content in Triticum aestivum L. Progress in Plant Protection, 56(2), 186-190. doi:10.14199/ppp-2016-031.

Martin, R. R., Naftel, S. J., Macfie, S., Skinner, W., Courchesne, F., \& Séguin, V. (2004). Time of flight secondary ion mass spectrometry studies of the distribution of metals between the soil, rhizosphere and roots of Populus tremuloides Minchx growing in forest soil. Chemosphere, 54, 1121-1125. doi:10.1016/j.chemosphere.2003.07.010.

Merrington, G., \& Smernik, R. J. (2004). Cadmium sorption in biosolids amended soil: result from a field trial. Science of the Total Environment, 327, 239-247. doi:10.1016/S0048-9697 (03)00166-9.

Miotto, A., Ceretta, C. A., Brunetto, G., Nicoloso, F. T., Girotto, E., Farias, J. G., Tiecher, T. L., de Conti, L., \& Trentin, G. (2014). Copper uptake, accumulation and physiological changes in adult grapevines in response to excess copper in soil. Plant and Soil, 374, 593-610. doi:10.1007/s11104-0131886-7.

Pernak, J., Syguda, A., Janiszewska, D., Materna, K., \& Praczyk, T. (2011). Ionic liquids with herbicidal anions. Tetrahedron, 67, 4838-4844. doi:10.1016/j.tet.2011.05.016.

PN-ISO 11047. (2001). Soil quality. Determination of Cd, Cr, Co, $\mathrm{Cu}, \mathrm{Pb}, \mathrm{Mn}, \mathrm{Ni}$ and $\mathrm{Zn}$ in extracts with aqua regia. Methods of flame and electrothermal atomic absorption spectroscopy. (in Polish).

Rosales-Conrado, N. (2009). Hydrolysis study and extraction of spiroxamine from soils of different physico-chemical properties. Chemosphere, 77(6), 821-828. doi:10.1016/j. chemosphere.2009.07.078.

Safari, Y., Delavar, M. A., Zhang, C., Esfandiarpour-Boroujeni, I., \& Owliaie, H. R. (2015). The influences of selected soil properties on $\mathrm{Pb}$ availability and its transfer to wheat (Triticum aestivum L.) in a polluted calcareous soil. Environmental Monitoring and Assessment, 187(12), 773. doi:10.1007/s10661-015-5001-9.

Sanz, A., Llamas, A., \& Ullrich, C. I. (2009). Distinctive phytotoxic effects of $\mathrm{Cd}$ and $\mathrm{Ni}$ on membrane functionality. Plant Signaling Behavior, 4(10), 980-982. doi:10.4161 /psb.4.10.9668.

Singh, A., Sharma, R. K., Agrawal, M., \& Marshall, F. M. (2010). Health risk assessment of heavy metals via dietary intake of foodstuffs from the wastewater irrigated site of a dry tropical area of India. Food and Chemical Toxicology, 48, 611-619. doi:10.1016/j.fct.2009.11.041.

Sivakumar, S., \& Subbhuraam, C. (2005). Toxicity of chromium(III) and chromium (VI) to the earthworm Eisenia fetida. Ecotoxicology and Environmental Safety, 62, 93-98. doi:10.1016/j.ecoenv.2004.08.006.

Stagnari, F., Onofri, A., Codianni, P., \& Pisante, M. (2013). Durum wheat varieties in $\mathrm{N}$-deficient environments and organic farming: a comparison of yield, quality and stability performances. Plant Breeding, 132, 266-275. doi:10.1111 /pbr. 12044.

Tarek, M., \& Shehata, S. (2015). Bioaccumulation and translocation of heavy metals by Plantago major L. grown in contaminated soils under the effect of traffic pollution. Ecological Indicators, 48, 244-251. doi:10.1016/j.ecolind.2014.08.013. 
Walker, D. J., Clemente, R., \& Bernal, M. P. (2004). Contrasting effects of manure and compost on soil $\mathrm{pH}$, heavy metal availability and growth of Chenopodium album L. in a soil contaminated by pyritic mine waste. Chemosphere, 57, 215224. doi:10.1016/j.chemosphere.2004.05.020.

Wang, S., Angle, J. S., Chaney, R. L., Delorme, T. A., \& Reeves, R. D. (2006). Soil pH effects on uptake of $\mathrm{Cd}$ and $\mathrm{Zn}$ by Thlaspi caerulescens. Plant and Soil, 281(1-2), 325-337. doi:10.1007/s11104-005-4642-9.

Wołejko, E., Wydro, U., Butarewicz, A., \& Łoboda, T. (2013). Effects of sewage sludge on the accumulation of heavy metals in soil and in mixtures of lawn grasses. Environment Protection Engineering, 39(2), 67-76. doi:10.5277 /EPE130207.

Wołejko, E., Butarewicz, A., Wydro, U., \& Łoboda, T. (2014). Advantages and potential risks of municipal sewage sludge application to urban soil. Desalination and Water Treatment, 52, 3732-3742. doi:10.1080/19443994.2014.884714.

Wuana, R. A., \& Okieimen, F. E. (2011). Heavy metals in contaminated soils: a review of sources, chemistry, risks and best available strategies for remediation. International Scholarly
Research Network Ecology, 2011, 1-20. doi:10.5402/2011 1402647.

Yoneyama, T., Gosho, T., Kato, M., Goto, S., \& Hayashi, H. (2010). Xylem and phloem transport of $\mathrm{Cd}, \mathrm{Zn}$ and $\mathrm{Fe}$ into grains of rice plants (Oryza sativa L.) grown in continuously flooded Cd-contaminated soil. Soil Science and Plant Nutrition, 56, 445-453. doi:10.1111 j.1747-0765.2010.00481.x.

Yruela, I. (2005). Copper in plants. Journal of Plant Physiology, 17(1), 145-156. doi:10.1590/S1677-04202005000100012.

Zaccone, C., Di Caterina, R., Rotunno, T., \& Quinto, M. (2010). Soil-farming system-food-health: effect of conventional and organic fertilizers on heavy metal $(\mathrm{Cd}, \mathrm{Cr}, \mathrm{Cu}, \mathrm{Ni}, \mathrm{Pb}, \mathrm{Zn})$ content in semolina samples. Soil and Tillage Research, 107(2), 97-105. doi:10.1016/j.still.2010.02.004.

Zadoks, J. C., Chang, T. T., \& Konzak, C. F. (1974). A decimal code for the growth stages of cereals. Weed Research, 14, 415-421.

Zhao, F. J., Hamon, R. E., \& McLaughlin, M. J. (2001). Root exudates of the hyperaccumulator Thlaspi caerulescens do not enhance metal mobilization. New Phytologist, 151, 613620. doi:10.1046/j.0028-646x.2001.00213.x. 